\title{
Importance of quinoa and amaranth in food security
}

\author{
S Chandra, P Dwivedi, MMV Baig \& LP Shinde
}

Journal of Agriculture and Ecology

ISSN: 2456-9410

Volume: 5

Journal of Agriculture and Ecology (2018) 5: 26-37

http://doi.org/10.53911/JAE.2018.5102 


\section{Importance of quinoa and amaranth in food security}

$\mathrm{S}$ Chandra ${ }^{1} \unrhd$, $\mathrm{P}$ Dwivedi ${ }^{2}$, MMV Baig ${ }^{3}$ and LP Shinde ${ }^{4}$

${ }^{1}$ Forensic Science Laboratory, Rohini, New Delhi, India.

${ }^{2}$ Department of $R \&$ D, Prajana Agro Associates, New Delhi, India.

${ }^{3}$ Department of Botany, Yashwant College, Nanded, Maharashtra, India

${ }^{4}$ Department of Chemistry, NES Science College, Nanded, Maharashtra, India

$\square \quad$ Corresponding author: S Chandra, E-mail: dr.chandra37@gmail.com

\section{Article Info}

Article history

Received: 14 February 2018

Accepted: 25 May 2018

Available online: 15

June 2018

\section{Key Words:}

Pseudocereals, gluten free grains, food security, value added food.
As a result of increasing population in the India and world, food security has become increasingly dependent on only a few crops with high demanding plant species. The quinoa (Chenopodium quinoa) and amaranth (Amaranthus spp.) are peculiar composition with high nutritional value and rich source of macronutrients and energy. These are called pseudocereals and provide good quality of protein, dietary fiber and lipids rich in unsaturated fatty acids. Amaranth and quinoa are gluten-free grains, having adequate levels of minerals, vitamins, and other bioactive components. Quinoa and amaranth is suitable for diverse consumers groups such as the elderly, children, high-performance athletes, diabetics, celiacs, and gluten or lactose intolerant people. Due to their composition and nutritional facts described for prospective for functional properties such as food supplements or common cereal replacers for human health. A review of the main aspects of amaranth and quinoa as alternative source of nutrient rich gluten free grains which have potential to alleviate hunger and provide food security to the Indian population. It is to be emphasized on the application of the amaranth and quinoa in the value added food for various segments of population; it will also create awareness to the farmers to grow these grains for better earning and livelihood.

\section{Abstract}

Copyright (C2018 Chandra et al., This is an open access article published under the terms of the Creative Commons Attribution License, which permits unrestricted use, distribution, and reproduction in any medium, provided the original work is properly cited.

Preferred citation: Chandra S, Dwivedi P, Baig MMV \& Shinde LP. 2018. Importance of quinoa and amaranth in global food security in India. Journal of Agriculture and Ecology, 5: 26-37; http://doi.org/10.53911/JAE.2018.5102.

\section{Introduction}

Globalization of agriculture and consequently its industrialization seem inexorable, with negative side effects felt throughout the India. These effects include but are not limited to, biased technological development of some high demanding plant species, monoculture production and in this way reduced genetic diversity in agriculture. As a consequence, Indian food security has become increasingly dependent on only a handful of crops. Over the time more than 10,000 edible species used by human, however only 150 plant species are commercialized on a significant global scale, 12 of which provide approximately $80 \%$ dietary energy from plants and over $60 \%$ of 
the global requirement for proteins and calories are met from rice, wheat, maize and potato. The narrowing of the number of crops upon which global food security and economic growth depend has placed the future supply of food and rural incomes at risk. The mentioned facts with profound environmental consequences and concern for loss of crop varieties stimulate organizations and scientists worldwide in retrieving, researching and disseminating the knowledge in production and utilization of neglected, disregarded, underexploited and new plant species, or so called alternative crops. Alternative crops plant species are used traditionally for food, fiber, fodder, oil or medicinal properties. Those are an under-exploited potential crop to contribute to food security, nutrition, health, income generation and environmental services. The aim of this review is to provide the main aspects of amaranth and quinoa for their applications in the food products.

\section{Quinoa}

Quinoa (Chenopodium quinoa) is a staple food of ancient civilizations and got originated in the Andean region of South America. In India quinoa find cultivated under "Project Anantha" in Ananthapuramu district of Andhra Pradesh few year back and also in Himalayan region. Now it is cultivated all over the India. Successful high yield cultivation was obtained in Uttar Pradesh. Quinoa is a pseudo cereal rather than a true cereal, as it is not a member of the true grass family. It is a small seed which look like a cross between sesame seeds and millets. Quinoa is a multipurpose crop for agricultural diversification. It is rich in various nutrients and its wider acceptability for development of various products and has numerous health benefits. This review paper describes recent results on the application of such pseudocereals as amaranth and quinoa, all possessing excellent nutrient profiles. However, it was noted that commercialization of these products is limited. Good sensory quality gluten-free foods produced from pseudocereals would be important for consumers with celiac disease in order to ensure an adequate intake of nutrients. Sensitivity to gluten results in a wide spectrum of manifestations triggered by ingestion of the gluten-containing grains such as wheat, barley and rye (Catassi \& Fasano 2008; Samadia \& Haldhar 2017). Due to these changes the improvement is usually observed by gluten withdrawal from the diet or inclusion of gluten free food products.

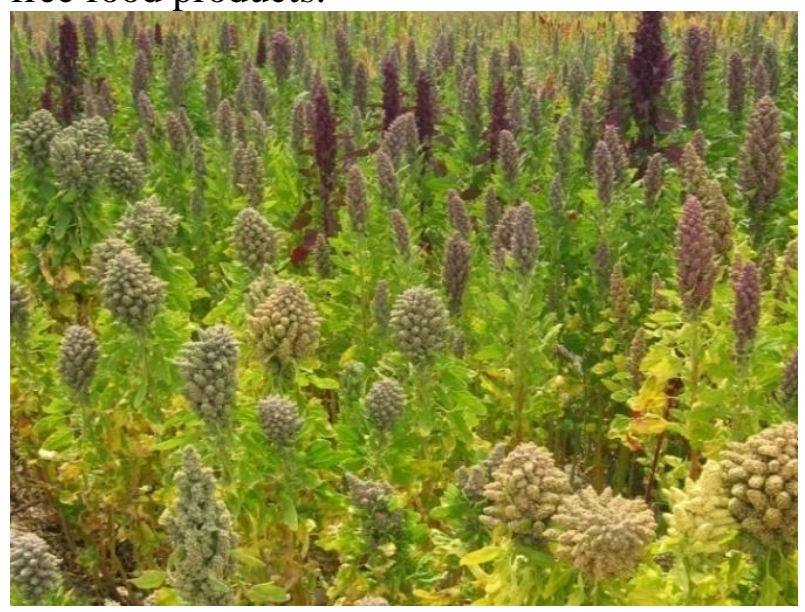

Fig.1 Quinoa Plants 


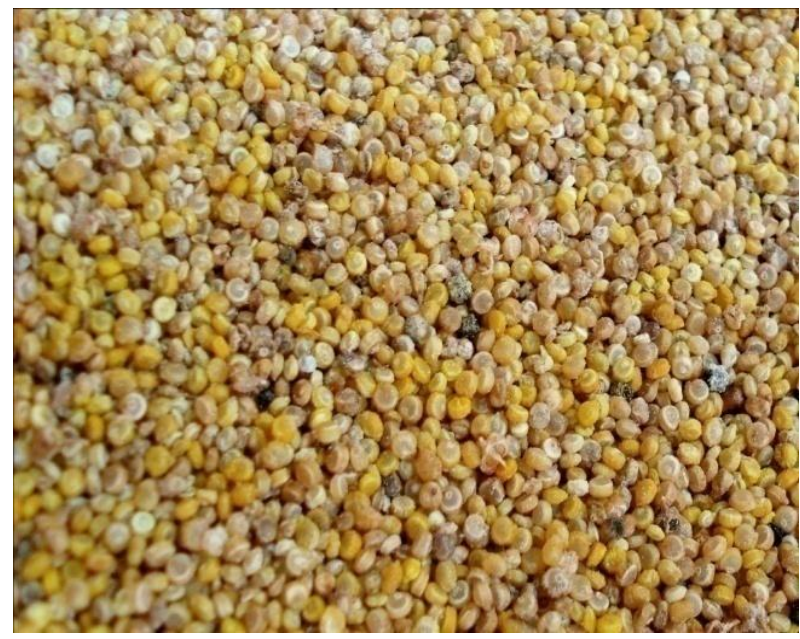

Fig. 2 Quinoa Grains

Quinoa is referred as pseudo-oilseed crop due to its exceptional balance between oil, protein and fats. Perisperm, embryo and endosperm are the three areas where reserve food is stored in quinoa seed. The nutritional value of quinoa grain has long been known to be superior to cereals and also gave similar value for starch content $(52-60 \%$ of grain weight). Quinoa starch has the potential that can be used for specialized industrial applications due to its small granules and high viscosity. The ash content of quinoa (3.4\%) is higher than that of rice $(0.5 \%)$, wheat $(1.8 \%)$ and other traditional cereals. Quinoa is a treasure of nutrients. It has exceptionally high protein (16-18\%) and more than $37 \%$ of the protein in quinoa comprises of essential amino acids like the milk protein, casein (Drzewiecki et al. 2003). The protein quality of quinoa grain is superior to most cereal grains including wheat. Albumin and globulins are the major protein fraction $(44-77 \%$ of total protein) while the percentage of prolamines is low $(0.5-0.7 \%)$, which indicates that it is free of gluten and, therefore, non-allergenic. Quinoa has shown some hypoglycemic effects and has been used as an alternative to traditional ingredients in the production of cereal-based gluten free products with a low Glycemic Index (Berti et al. 2004). Several studies have revealed that the oil content in quinoa ranges from 1.8 to $9.5 \%$, with an average of $5.0-7.2 \%$ that is higher than that of maize (3-4\%).Quinoa oil is rich in essential fatty acids, like linoleate and linolenate (Koziol 1992) and has a high concentration of natural antioxidants like $\alpha$-tocopherol (5.3 $\mathrm{mg} / 100 \mathrm{~g})$ and $\beta$-tocopherol $(2.6 \mathrm{mg} / 100 \mathrm{~g}$ ) and appreciable amounts of thiamin (0.4 $\mathrm{mg} / 100 \mathrm{~g})$, folic acid $(78.1 \mathrm{mg} / 100 \mathrm{~g})$ and vitamin C (16.4 mg/100 g) (Ruales \& Nair 1992). Quinoa contained total dietary fiber content of $13.4 \%$ in quinoa consisting of $11.0 \%$ insoluble fiber and $2.4 \%$ soluble fiber. Quinoa's fatty acids have been shown to maintain their quality because of quinoa's naturally high value of vitamin $\mathrm{E}$, which acts as a natural antioxidant. The riboflavin and carotene content as $0.39 \mathrm{mg} / 100 \mathrm{~g}$ and 0.39 $\mathrm{mg} / 100 \mathrm{~g}$ respectively (Koziol 1992). In terms of $100 \mathrm{~g}$ edible portion, quinoa supplies 0.20 $\mathrm{mg}$ vitamin B6, $0.61 \mathrm{mg}$ pantothenic acid, $23.5 \mu \mathrm{g}$ folic acid and $7.1 \mu \mathrm{g}$ biotin. Quinoa grains contain large amounts of minerals like $\mathrm{Ca}, \mathrm{Fe}, \mathrm{Zn}, \mathrm{Cu}$ and $\mathrm{Mn}$ (Repo-Carrasco et al. 2003). Large amounts of iron $(81 \mathrm{mg} / \mathrm{kg})$ and calcium $(874 \mathrm{mg} / \mathrm{kg})$ was reported in quinoa. It has about $0.26 \%$ of magnesium in comparison to $0.16 \%$ of wheat and $0.14 \%$ of corn (Ruales \& Nair 1992).

Quinoa may also be germinated to enhance its nutritional value. Germination activates its natural enzymes, improves its vitamin status and softens the grain. Quinoa 
has a short germination period of 2-4 hours as other grains require 12-14 hours germination process overnight. The proximate composition quinoa and amaranth along with other major grains are given in table 1 .

Table 1 Proximate composition of quinoa, amaranth and other major grains (\%)

\begin{tabular}{lcccccc}
\hline Seed & Moisture & Ash & Protein & Fat & Carbohydrates & $\begin{array}{c}\text { Crude } \\
\text { fiber }\end{array}$ \\
\hline Quinoa & $10-13$ & 3 & $12-19$ & $5-10$ & $61-74$ & $2-3$ \\
$\begin{array}{l}\text { Amaranth } \\
\text { peniculatas }\end{array}$ & $6-9$ & $3-4$ & $13-18$ & $6-8$ & 63 & $4-14$ \\
Wheat & 13 & 2 & 14 & 2 & 69 & 1 \\
Oats & 8 & 2 & 14 & 8 & 68 & 1 \\
Rice & 15 & 1 & 8 & 1 & 78 & 2 \\
Maize & 15 & 2 & 13 & 4 & 66 & 2 \\
Sorghum & 12 & 2 & 12 & 2 & 73 & 2 \\
Soybean & 8 & 5 & 47 & 21 & 14 & 4 \\
Barley & 13 & $2-3$ & 12 & 1 & 70 & 4
\end{tabular}

Source: Bressani 2003; Copeland 2009

\section{Health benefits of quinoa}

Celiac disease most common lifelong disorders worldwide with an estimated mean prevalence of $1 \%$ of the general population. The only acceptable treatment for celiac disease is the strict lifelong elimination of gluten from the diet (Catassi \& Fasano 2008). The prevalence of celiac disease among school children in Ludhiana district of Punjab, North India and final analysis was studied that the disease prevalence was one in 310 children (Sood et al. 2006). The ratio of villus height to crypt depth improved from slightly below normal values (2.8:1) to normal levels $(3: 1)$, the addition of quinoa to the gluten free diet of celiac patients was well tolerated and did not exacerbate the condition (Zevallos et al. 2014). Quinoa is a mild laxative, good for insomnia, combats dandruff and is a good hair tonic. Likewise, the cooking water from the cooked grain mixed with milk and almond oil is used to wash the ears where there is pain, noise and deafness. The broth, soup or warm grain of quinoa is nutritive tonic, increases breast milk, is restorative and protects against tuberculosis. Quinoa soup immediately increases the milk supply of lactating women. It is a good sudorific is produced by cooking five tablespoons of quinoa seeds in two bottles of water. The same decoction, sweetened with honey or molasses, is a proven remedy against bronchial disorders, colds, cough and inflammation of the tonsils. The fresh leaves 
of quinoa 'chiwa', consumed either as a soup or dessert, are a remedy against scurvy and other illnesses or diseases caused by vitamin deficiency. It is a proven remedy against anthrax, herpes and other skin conditions.

\section{Product development}

The pseudocereal proved to be a suitable substrate for dough aeration using yeast, since considerably more glucose and a higher activity of $\alpha$-glucosidase were found in comparison to rice and corn flour. Quinoa white flour enhanced the specific volume by $33 \%$. Moreover, the crumb featured homogeneous and finely distributed gas bubbles and the taste was not compromised. Thus, it was possible to improve the quality of gluten-free bread by using quinoa white flour, which might be a relief for celiac patients. Quinoa may also be germinated to boast its nutritional value. Germination activates its natural enzymes, improves its vitamin status and softens the grain. Quinoa can be cooked as a cereal such as porridge, used as an alternative to rice or poha, add it to salads, dessert or even can be used to thicken the soups. It can be used as flour for preparation of gluten free bread and bakery products. Calcium, magnesium and iron are minerals that are deficient in gluten-free products and in the gluten-free diet (Hopman et al. 2006). The pseudocereals quinoa is generally a good source of these and other important minerals (Alvarez et al. 2009). The cake quality was acceptable with $5 \%$ to $10 \%$ of quinoa flour. Cake flavor improved up to $20 \%$ quinoa flour blended (Lorenz 2002). Both unprocessed and processed quinoa samples were subjected to successive extractions in methanol and ethyl

acetate solvents. Quinoa flour subjected to processing via roasting and extrusion resulted in a significant impact on the chemical profile when compared to unprocessed quinoa flour. Steam pre-conditioning had minimal effects on the chemical profile of quinoa flour. It is suggested that thermal processing of quinoa flour can result in degradation of saponin molecules. Saponin decomposition may influence sensory or pharmacological properties (Brady 2007). The unique property of quinoa starch was its unusual freeze-thaw stability, a fact difficult to explain. The opaque nature of quinoa starch paste suggests applications in emulsion food products such as salad dressings (Ahamed et al. 1996). The rheological properties of doughs prepared from wheat flour with buckwheat and quinoa flour addition (2.5 mass \%, 5.0 mass \%, 7.5 mass $\%$, and 10 mass \%) was investigated using a farinograph and compared with those of standard dough (without pseudocereals). Doughs containing quinoa flour were more stable than those with buckwheat flour addition. From the comparison of the studied characteristics it can be concluded that an addition of lower amounts of quinoa (up to 5.0 $\%$ ) to wheat flour will not significantly impair rheological properties of the dough but provides for enhanced nutritional value of the prepared bakery products (Jancurova 2009). Quinoa has shown some hypoglycemic effects in vivo and has been recommended as an alternative to traditional ingredients in the production of cereal-based gluten-free products with a low GI (Berti et al. 2004).

\section{Quinoa- Indian perspective}


India located between $8^{\circ}$ and $38^{\circ} \mathrm{N}$ and $68^{\circ}$ and $93.5^{\circ} \mathrm{E}$, exhibits enormous diversity for agro-climatic regions and edapho-climatic conditions. An increasing population in this region of the world demands not only an increase in food grain production but also a shift towards environmentally sound sustainable agriculture. In India, a large portion of the population has little access to protein-rich diet, since rice and wheat are the principal food crops. Quinoa's highly proteinaceous grain can help to make diets more balanced in this region. Making quinoa popular in India would require dissemination of information about the crop among the farmers as well as the consumers, proper marketing and efficient post-harvest technologies. Quinoa has the potential to shed its underutilized status and become an important industrial and food crop of the $21^{\text {st }}$ century. The narrowing of the number of crops upon which global food security and economic growth depend has placed the future supply of food and rural incomes at risk. The mentioned facts with profound environmental consequences and concern for loss of crop varieties stimulate organizations and scientists worldwide in retrieving, researching and disseminating the knowledge in production and utilization of neglected, disregarded, underexploited and new plant species, or so called alternative crops. Quinoa, Chenopodium quinoa Willd is indigenous pseudocereals domesticated from Andean region in South America and have potential agronomic importance across the world. These crops are highly nutritious and environmentally resistant. They can be adapted to different environmental conditions, being cultivated on poor soils and high altitudes (Gorinstein et al. 2007, Rosell et al. 2009). At present, consumption of alternative crops has attracted much interest as potential recipes for healthy food production and dietary uses. The opportunity to supplement or completely replace common cereal grains (corn, rice or wheat) with a higher nutritional value cereal (such as quinoa) is becoming popular among people interested in improving and maintaining their health status by changing dietary habits.

\section{Amaranth}

Amaranth belongs to the order Caryophyllales, family Amaranthaceae, genus Amaranthus, and section Amaranthus (Berghofer \& Schoenlechner 2002). The genus Amaranthus includes about 60 species, most of which are cosmopolitan weeds associated with difficulties in cultivation practices after soil disturbance and seed exposure to light (Grobelnik, et al. 2009). The three species of genus Amaranthus originated from South America and considered as grain production are $A$. hypochondriacus L. (México), A. cruentus L. (Guatemala), and A. caudatus L. (Bressani 2003). 


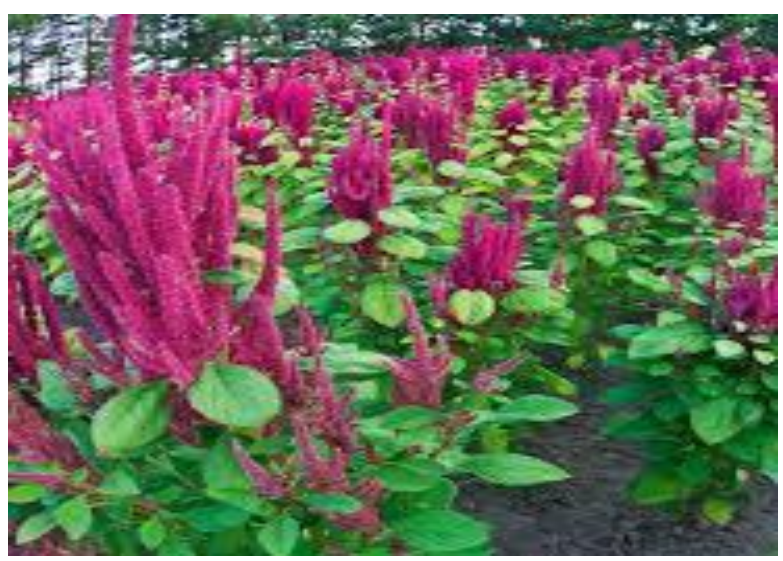

Fig. 3 Amaranth Plants

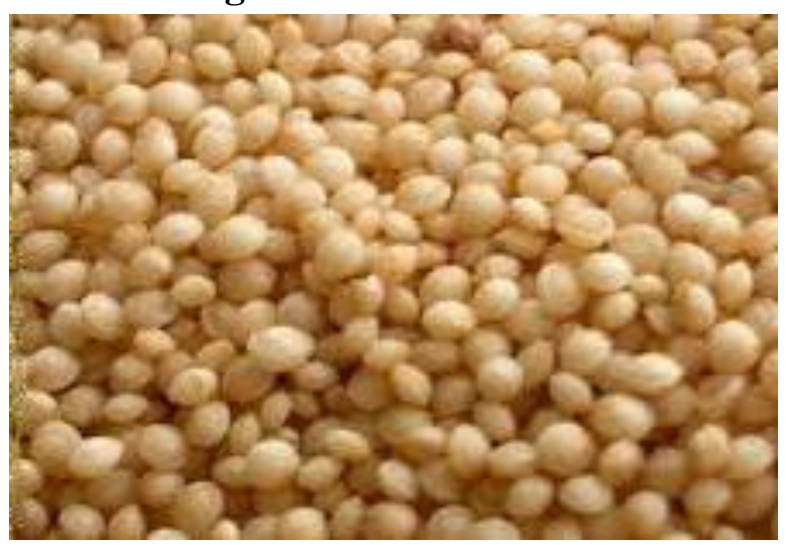

Fig. 4 Amaranth Grains

In amaranth seeds, the embryo or germ is campylotropous and surrounds the starch-rich perisperm like a ring and together with the seed coat represent the bran fraction, which is relatively rich in fat and protein (Bressani 2003; Prego et al. 1998). The percentage of bran fraction is higher in amaranth seeds in comparison with common cereals, which explains the higher levels of protein and fat present in these seeds (Bressani 2003). In amaranth the seed coat is smooth and thin, thus it is not necessary to remove it (Irving et al. 1981). The main seed storage tissue is perisperm (diploid in chromosome number), and not endosperm which is present only in the micropylar region of the seed (Prego et al. 1998).

\section{Health benefits of Amaranth}

The nutritional value of Amaranth is main source of proteins content 14.0-16.5\% that are an important group of biomacromolecules involved in physiological functions (Gorinstein, et al. 2002). The protein is located in the embryo and contrarily to common grains such as wheat, the proteins are composed mainly of globulins and albumins, and containing very little or no storage prolamin proteins in Amaranth, which are the main storage proteins in cereals and the toxic proteins in celiac disease (Valencia 2008; Alvarez et al. 2010; Grobelnik et al. 2009). Amaranth proteins consist of about $40 \%$ albumins, 20\% globulins, 25-30\% glutelins, and $2-3 \%$ prolamins (Schoenlechner et al. 2008).

Amaranth protein shows an excellent source of amino acid pattern but leucine are present in amounts slightly lower than other cereals, suggesting that it could be necessary the combination of amaranth with any other cereals to reaches the recommended requirements (Becker et al. 1981; Grobelnik et al. 2009). Regarding to the FAO/WHO, they suggested preschool requirements, amaranth protein have adequate levels of tryptophan, histidine, valine, phenylalanine, lysine and threonine. The high bioavailability of pseudocereal's protein has been shown in several studies (Gamel 2004; Koziol 1992; Ruales \& Nair1992). Gamel (2004) observed that lysine was the limiting amino acid in popped samples of amaranth. They also 
observed a high loss of tyrosine followed by phenylalanine and methionine.

Carbohydrates are components that contribute $50-70 \%$ of dietary energy and are classified according to their degree of polymerization into three principal groups: sugars (monosaccharides, disaccharides, polyols), oligosaccharide, and polysaccharides (starch and nonstarch) (Copeland 2009). Amaranth can be considered nutraceutical foods because they have hypocholesterolemic effects (Yamani \& Lannes 2012) and induce lowering of free fatty acids (Berti et al. 2004). In amaranth, starch comprises the main component of carbohydrates, but lower than in cereals. Amaranth starch is located in the perisperm, where typical compounded starch particles that can reach a length of $90 \mu \mathrm{m}$ in diameter are generated in the amyloplasts. The amylose content of amaranth starch is lower than that in other cereal starches, with values varying from $0.1 \%$ to $11.1 \%$ (Schoenlechner et al. 2010). Physical properties such as viscosity, higher solubility and gelatinization temperature range, higher sorption capacity at high water activity range, higher solubility, swelling power, water-binding capacity, and enzyme susceptibility (Choi et al. 2004), can be explained by the small size of the starch granule as well as its high amylopectin content. However, when selecting genotypes for particular processing purposes, it need to be taken into account the genetic diversity in physical properties of starch and variations in the other constituents (proteins, lipids, minerals), which have an influence on starch functional properties within and among amaranth species (Grobelnik 2009). Danz \&
Lupton (1992) have examined the effects of dietary amaranth fiber on serum and liver lipids in male rats receiving cholesterolsupplemented diets providing approximately 8 $\%$ dietary fiber. Amaranth resulted in lower serum cholesterol values than those of fiberfree controls and lower liver cholesterol values than those of cellulose. According to Dodok et al. 1997; Grobelnik et al. 2009, in amaranth oil, between $75-77.1 \%$ of fatty acids are unsaturated. Linoleic acid is the most abundant fatty acid (47.5-47.8 for amaranth), followed by oleic acid (23.7-32.9 in amaranth) and palmitic acid (12.3-20.9 in amaranth) (Alvarez et al. 2009; Bruni et al. 2001).

Amaranth also is a good source of riboflavin $(0.19-0.23 \%)$ and ascorbic acid (4.50\%). Becker (1981) analyzed some amaranth samples for ascorbic acid content and found amounts ranging from 3.36 to 7.24 $\mathrm{mg} / 100 \mathrm{~g}$. Furthermore amaranth is excellent sources of vitamin $\mathrm{E}$, which contributes to the prolonged stability of the oil.

Calcium, magnesium and iron are minerals that are deficient in gluten-free products and in the gluten free-diet. The Amaranth is a good source of these and other important minerals can assist to reduce this deficiency (Alvarez et al. 2010). In general, the content of minerals in amaranth is about twice as high as in other cereals. In amaranth, polyphenols can be found in amounts ranging from 14.72 to $14.91 \mathrm{mg} / 100 \mathrm{~g}$. Tannins are polyphenolic secondary plant metabolites of higher plants, which can be found in high concentrations in the hulls of cereals and legumes (Schoenlechner et al. 2008). Becker et al. (1981) evaluated 10 different samples of 
amaranth and found a range of $80-420 \mathrm{mg} / 100$ $\mathrm{g}$ of tannins. Also values of tannin contents varying from 0 to $500 \mathrm{mg} / 100 \mathrm{~g}$, in quinoa, have been reported (Chauhan et al.1992).

\section{Importance of quinoa and amaranth}

Amaranth and quinoa grains is used in a wide variety of foods such as tasteful soups, sweets, beverages, sauces, porridges, and souffles can be prepared. Various hot or fermented drinks can also be produced. The grains are germinated for sprouts and malted for beer production. The fermented beverage made from amaranth and quinoa seeds are called chichi (Early 1990). Quinoa is used frequently to prepare coarse bread called kispina (Lorenz \& Coulter 1991). They also serve as starchy material, and protein concentrates, and flours can be produced. Amaranth grain rolled or popped can be used in breads, muesli and in granola bars. Grain can be ground and used as a flour ingredient in different mixtures for pancakes, breads, muffins, crackers, dumplings, cakes, cookies, pasta, puddings, etc (Alvarez et al. 2010). Proteins of other cereal grains, are not supposed to be capable of forming dough. Then, mixtures of wheat flour and other cereals are used in order to obtain bakery products. At the moment, amaranth and quinoa are potential sources of food due to their high quality of proteins (Gross et al. 1989). The main problem in the use of quinoa and amaranth as components, replacing wheat in the blends, arises from the fact that these pseudocereals do not contain gluten, and thus the addition into leavened and pasta products are limited (Grobellnk et al. 2009). Hence, when amaranth and quinoa flours are used to make leavened bread as composite with wheat flour (Taylor et al. 2002).

\section{Application of Amaranth and Quinoa}

Several workers have been investigated applications of amaranth and quinoa seeds in various food products as it can act as promising foods on the account of its nutritional qualities and to complement other cereals as supplements for adding nutritional value (Sindhuja et al. 2005). Tosi et al. 2002 reported that whole and defatted hyperproteic amaranth flours, reported a gradual decrease in volume and specific volume with respect to control breads at increasing substitution levels for both amaranth flours. Also a deleterious effect was noticed in the bread score values formation. The gluten-free products currently available in the market are considered of low quality and poor nutritional value (Alvarez et al. 2009; Alvarez et al. 2010). The fact that amaranth and quinoa do not contain gluten could be advantageous for people suffering from celiac disease and wheat allergy or intolerance (Taylor et al. 2002). The antioxidant capacity was significantly increased. Bread volumes were found to increase for buckwheat and quinoa breads in comparison with the control and all the pseudocereal-containing breads were characterized by a significantly softer crumb structure (Alvarez et al. 2010). Salas (2011) formulated products (cakes and fillings for chocolate and bakery products) with functional characteristics, adding nutritional value, using quinoa as one of the main ingredient because of high content of nutrients and free of gluten. The application of quinoa and corn mixtures in the production of a 
gluten-free spaghetti-type product was studied by (Caperuto et al. 2000). Tosi et al. (1996) used whole amaranth flour to develop glutenfree biscuits with higher protein content. The authors also found that the addition of $0.1 \%$ butylated hydroxytoluene (BHT) extended the shelf-life without affecting the flavor.

\section{Conclusions}

Quinoa and Amaranth are potential crops for food security across the world. Owing to their high nutrient content and quality of proteins. These are essentially composed by globulins and albumins which contain less glutamic acid and proline than prolamins, and high essential amino acids content such as lysine, methionine, cystine, and histidine. Making quinoa popular in India would require dissemination of information about the crop among the farmers as well as the consumers, proper marketing and efficient postharvest technologies. Quinoa has the potential to shed its underutilized status and become an important industrial and food crop of the $21^{\text {st }}$ century.

\section{References}

Ahamed NT, Singhal RS, Kulkarni PR \& Pal M. 1996. Physicochemical and functional properties of Chenopodium quinoa starch. Carbohydrate polymers, 31: 99-103.

Alvarez-Jubete L, Arendt EK \& Gallagher E. 2009. Nutritive value and chemical composition of pseudocereals as glutenfree ingredients. International Journal of Food Sciences and Nutrition, 60: 240-257.

Alvarez-Jubete L, Auty M Arendt EK \& Gallagher E. 2010. Baking properties and microstructure of pseudocereal flours in gluten-free formulations. European Food Research and Technology, 230: 437-445.

Becker R, Wheeler E L, Lorenz K, Stafford AE, Grosjean OK, Betschart AA \& Saunders RM. 1981. A compositional study of amaranth grain. Journal Food Science, 46: 1175-1180.

Berghofer E \& Schoenlechner R. 2002. Grain Amaranth. In: Belton P, Taylor J (eds), Pseudocereals and less common cereals, grain properties and utilization potential. Springer- Verlag, pp.219-60.

Berti C, Riso P, Monti L \& Porrini M. 2004. In vitro starch digestibility and in vitro glucose response of gluten-free foods and their gluten counterparts. European Journal of Nutrition, 43: 198-204.

Brady K, Ho CT, Rosen RT, Sang S \& Karwe MV. 2007. Effects of processing on the nutraceutical profile of quinoa. $\mathrm{J}$ food chem 100:1209-1216.

Bressani R. 2003. Amaranth. In B. Caballero (ed.), Encyclopedia of food sciences and nutrition. Oxford: Academic Press, pp.166-173.

Bruni R, Medici A, Guerrini A, Scalia S, Poli F, Muzzoli M \& Sacchetti G. 2001. Wild Amaranthus caudatus seed oil, a nutraceutical resource from Ecuadorian flora. Journal of Agricultural and Food Chemistry, 49: 5455-5460.

Caperuto L, Amaya-Farfan J \& Camargo C. 2000. Performance of quinoa (Chenopodium quinoa Willd.) flour in the manufacture of gluten-free spaghetti. Journal of the Science of Food and Agriculture, 81: 95-101.

Catassi C \& Fasano A. 2008. nutritive value of pseudocereals and their increasing use as functional gluten free ingredients. Journal of Food Science and Technology, 21:106-113.

Chauhan GS, Zillman RR \& Eskin NAM. 1992. Dough mixing and breadmaking properties of quinoa-wheat flour blends. 
International Journal of Food Science and Technology, 27: 701-705.

Choi H, Kim W \& Shin M. 2004. Properties of Korean amaranth starch compared to waxy millet and waxy sorghum starches. Starch/Starke, 56: 469-477.

Copeland L. 2009. Structural characterization of wheat starch granules differing in amylase content and functional characteristics. Carbohydrate Polymers, 75: 705-711.

Danz RA \& Lupton JR.1992. Physiological effects of dietary amaranth (Amaranthus cruentus) on rats. Cereal Food World, 37: 489-494.

Dodok L, Modhir AA, Buchtova V, Halasova, G, Polacek I. 1997. Importance and utilization of amaranth in food industry. Part 2. Composition of amino acids and fatty acids. Nahrung, 41: 108-110.

Drzewiecki J, delgado-licon E, haruenkit $\mathrm{R}$, pawelzik E, Martin-Belloso O \& Park YS. 2003. Identification and differences of total proteins and their soluble fractions in some pseudocereals based on electrophoretic patterns. Journal of Agriculture Food Chemistry, 51:77987804.

Early DK. 1990. Amaranth production in Mexico and Peru. In Janick and J.E. Simon (eds), Advances in new crops. Timber Press, Portland, OR. pp.140-142,

Gamel TH, Linssen JP, Alink GM, Mossallem AS \& Shekib LA. 2004. Nutritional study of raw and popped seed proteins of Amaranthus caudatus L and Amaranthus cruentus L. Journal Science and Food Agriculture, 84: 1153-1158.

Gorinstein S, Medina-Vargas O, Jaramillo N, Arnao Salas I, Martinez Ayala A, Arancibia-Avila P, Toledo F, Katrich E \&
Trakhtenberg S. 2007. The total polyphenols and the antioxidant potentials of some selected cereals and pseudocereals. European Food Research and Technology, 225: 321-328.

Gorinstein S, Pawelzik E, Delgado-Licon E, Haruenkit R, Weisz M, Trakhtenberg S. 2002. Characterisation of pseudocereal and cereal proteins by protein and amino acid analyses. Journal of the Science of Food and Agriculture, 82: 886-891.

Grobelnik MS, Turinek M, Jakop M, Bavec M \& Bavec F. 2009. Nutrition value and use of grain amaranth: potential future application in bread making. Agricultura, 6: 43-53,

Gross R, Koch F, Malaga I, Miranda AF, Schoeneberger H \& Trugo LC. 1989. Chemical composition and protein quality of some local Andean food sources. Food Chemistry, 34: 25-34.

Hopman EG, Le Cessie S, Von Blomberg ME \& Mearin ML. 2006. Nutritional management of the gluten- free diet in young people with celiac disease. Journal of Pediatric Gastroenterology Nutrition, 43:102-108.

Jancurova M, Minarovicova L, Dandar A. 2009. Rheological properties of doughs with buckwheat and quinoa additives. Chemical Papers, 63:738-741.

Koziol MJ. 1992. Chemical composition and nutritional evaluation of quinoa (Chenopodium quinoa Willd). Journal of Food Composition Analysis, 5: 35-68.

Lorenz K, Coulter L. 1991. Quinoa flour in baked products. Plan Foods for Human Nutrition, 41: 213-223.

Prego I, Maldonado S \& Otegui M. 1998. Seed structure and localization of reserves 
in Chenopodium quinoa. Annals of Botany, 82: 481-488.

Repo-Carrasco R, Espinoza C \& Jacobsen S. 2003. Nutritional value and use of the Andean crops quinoa (Chenopodium quinoa) and kan iwa (Chenopodium pallidicaule). Food Revolution International, 19: 179-189.

Rosell CM, Cortez G, Repo-Carrasco R. 2009. Breadmaking use of the Andean crops quinoa (Chenopodium quinoa), kañiwa (Chenopodium pallidicaule), kiwicha (Amaranthus caudatus), and tarwi (Lupinus mutabilis). Cereal Chemeistry, 86: 386-392.

Ruales J \& Nair BM. 1992. Nutritional quality of the protein in quinoa (Chenopodium quinoa Willd) seeds. Plant Foods Human Nutrition, 42:1-12.

Salas AGV. 2011. Development of quinoa (Chenopodium quinoa Willd.) based products with functional characteristic. 106 p. Master Science Thesis Pharmaceutical Sciences School, University of Sao Paulo, Sao Paulo-Brazil (Advisor: Suzana Caetano da Silva Lannes).

Samadia DK \& Haldhar SM. 2017. Breeding strategies and scope of improvement in arid zone fruit crop-plants under abiotic stressed agro-climate: an analysis. Journal of Agriculture and Ecology, 4: 1-13.

Schoenlechner R, Drausinger J, Ottenschlaeger V, Jurackova K \& Berghofer E. 2010. Functional properties of gluten-free pasta produced from amaranth, quinoa and buckwheat. Plant Foods for Human Nutrition, .65: 339-349.

Schoenlechner R, Siebenhandl S, Berghofer E. 2008. Pseudocereals. In: Arendt, E.K., Bello, F.D. editors. Gluten-free cereal products and beverages. Academic Press. Chapter 7. pp. 149-190.

Sindhuja A, Sudha ML \& Rahim A. 2005. Effect of incorporation of amaranth flour on the quality of cookies. European Food Research and Technology, 221: 597-601.

Sood Ajit, Midha V, Sood N, Avasthi G \& Sehgal A. 2006. prevalence of celiac disease among school children in punjab, north India. Journal of Gastrology \& Hepatology, 21: 1622-1625.

Taylor J R N, Parker M L. 2002. Quinoa. In P. S. Belton, and J. R. N. Taylor (eds.), Pseudocereals and less common cereals: Grain properties and utilization. Berlin: Springer Verlag, pp. 93-122.

Tosi EA, Ciappini MC \& Mascarelli R. 1996. Utilización de la harina integral de amaranto (Amaranthus Cruentus) In: La Fabricación de galletas para celíacos. Alimentaria, pp.49-55.

Tosi EA, Re ED, MasciarelliR, Sanchez H, Osella C \& de La Torre MA. 2002. Flour tested as wheat flour supplementation in mold breads. Lebensmittel-Wissenschaft und Technologie, 35: 472-475.

Valencia-Chamorro SA. 2008. Quinoa. In: Caballero B. Encyclopedia of Food Science and Nutrition, vol. 8. Academic Press, Masterdam. pp.4895-4902.

Yamani BV \& Lannes SCS. 2012. Applications of Quinoa (Chenopodium Quinoa Willd.) and Amaranth (Amaranthus Spp.) and their influence in 
the nutritional value of cereal based

foods. Food and Public Health, 2: 265275.

Zevallos VF, Herencia LI, Chang F, Donnelly S, Ellis HJ \& Ciclitira PJ. 2014. Gastrointestinal effects of eating quinoa (chenopodium quinoa wild) in celiac patients. The American Journal of Gastrology, 109: 270-278. 